\title{
First Dental Visit of a Child - Perspectives of Parents / Guardians and Dentists / Paediatric Dentists in Saudi Arabia
}

\author{
Ullal Anand Nayak¹, Ahad Fahd AlQahtani², Rewaa Fadil Alturkistani³, Afnan Ali Al-Kendi , Mai Awad Aljuaid ${ }^{5}$ \\ 1, 2, 3, 4, 5 Department of Preventive Dental Sciences, Ibn Sina National College for Medical Studies, Jeddah, Saudi Arabia.
}

\section{ABSTRACT}

\section{BACKGROUND}

The appropriate timing of first dental visit has an influence on child's oral health care and determines the effectiveness of preventive dental care rendered. The present study assesses the attitudes and practices of parents / guardians as well as dentists / paediatric dentists towards the first dental visit of children and evaluate as to whether there is any difference in their perception.

\section{METHODS}

151 parents, 101 general dentists, and 53 paediatric dentists, were selected randomly from government and private institutions or hospitals across Saudi Arabia. Two separate close-ended, multiple-choice questionnaires were directed to evaluate the knowledge, attitude and practice of parents / guardians as well as general / paediatric dentists towards their child's first dental visit. Chi square test was used to find the association of variables.

\section{RESULTS}

Most parents preferred to take their children for first dental visit between 3 to 6 years, for the reason of pain (31.8\%) or prevention of caries (31.8\%). $98 \%$ of parents were happy with their child's first dental visit and $84.8 \%$ would surely go for follow - up visits for treatment. $86.8 \%$ of paediatric dentists recommended first dental visit within 6 years of age when compared to $52.4 \%$ of general dentists [p = 0.001]. Paediatric dentists were more frequently recording general health / growth, performing extra - oral \& intra - oral examinations and evaluating developingdentition, when compared to general dentists $[p=0.001]$.

\section{CONCLUSIONS}

There is an urgent need for the general dental practitioners as well as paediatric dentists to educate and motivate the parents regarding the first dental visit and its objectives.

\section{KEY WORDS}

First Dental Visit, Paediatric Dentist, General Dentist
Corresponding Author: Dr. Ullal Anand Nayak, Associate Professor, Department of Preventive Dental Sciences, Ibn Sina National College for Medical Studies, Jeddah, Saudi Arabia.

E-mail: pediatricdentist4u@gmail.com

DOI: $10.14260 / j e m d s / 2020 / 678$

How to Cite This Article:

Nayak UA, AlQahtani AF, Alturkistani RF, et al. First dental visit of a child - perspectives of parents / guardians and dentists / paediatric dentists in Saudi Arabia. J Evolution Med Dent Sci 2020;9(42):30863091, DOI: $10.14260 /$ jemds/2020/678

Submission 14-06-2020,

Peer Review 12-09-2020,

Acceptance 19-09-2020,

Published 19-10-2020.

Copyright $@ 2020$ Ullal Anand Nayak et al. This is an open access article distributed under Creative Commons Attribution License [Attribution 4.0 International (CC BY 4.0)] 


\section{BACKGROUND}

Intention of scheduling a dental visit at an early age in children is to introduce the preventive strategies to the parents so that the child's dental care can be appropriate and optimal oral health is achieved. Year one dental visit helps to accomplish an anticipatory guidance and establish dental home. ${ }^{1}$ Early childhood caries is a significant health issue that can induce pain and cause psychological trauma to these children. Hence, the importance of prevention of dental caries in children should be targeted at a younger age so that maximum oral and general health related benefits can be reaped. The parent's attitude and practices of dental health and treatment could influence the oral health status of their children. It is observed that when parents have positive approach and seriousness regarding dental health, their children are more likely to exhibit better oral health. ${ }^{2}$

Parents who have limited knowledge related to the timing of first dental visit for their children, are likely to have negative consequences. ${ }^{3}$ Numerous risk factors have been documented for development of early childhood caries such as prolonged breastfeeding, frequent nocturnal bottle feeding, oral hygiene practices, diet, timing, and reason for the first visit of a child to the dentist which could be focused on if the parents arrive early for dental treatment. ${ }^{4}$

A child's behaviour during the first dental visit is reported to considerably influence the likelihood of future recall visits 5 and hence, there is ample need to raise awareness among parents regarding the importance of taking oral health care of their children quite seriously during the early stage of their life. ${ }^{6}$

Hence, in light of the aforementioned facts and observations, a cross - sectional questionnaire - based study was planned and undertaken in order to adequately assess the attitudes and practices of parents / guardians as well as dentists / paediatric dentists towards the first dental visit of children and also to evaluate whether there is any difference in their perception.

\section{METHODS}

\section{Study Design and Duration}

A cross - sectional study was planned for a period of six months from 15th August 2019 to $15^{\text {th }}$ February 2020 among 151 parents, 101 general dentists and 53 paediatric dentists. Two separate close-ended, multiple-choice questionnaires were prepared to evaluate the knowledge, attitude and practice of parents / guardians as well as general / paediatric dentists of Saudi Arabia towards child's first dental visit. The questionnaire for parents / guardians comprised of 10 questions whereas that for general / paediatric dentists consisted of 18 questions, 6 each pertaining to knowledge, attitude and practice. Both questionnaires were validated, and their construct, face, and content validities were carried out with the help of 5 randomly selected dentists with vast clinical and teaching experience. The difficulty in understanding each question, its interpretation, and its correctness were critically analysed. The modifications were accordingly, carried out and the proforma was finalized.

\section{Ethical Approval}

The institutional ethical committee of Ibn Sina National College for Medical Studies, Jeddah approved the ethical clearance for the study. The participants who consented for the study were ensured that their participation would be kept confidential.

\section{Inclusion and Exclusion Criteria}

The parents / guardians who had accepted to participate in the study and those children who would visit the dentist for the first time were included in the study. Any mental / physical disability among the parent, guardian or children lead to their exclusion from the study. The general dentists and paediatric dentists were selected randomly from government and private institutions and / or hospitals across Saudi Arabia.

\section{Data Collection}

The questionnaire for parents was translated into local (Arabic) language for ease of understanding by the participants. The questions were targeted to obtain information regarding the child's first dental visit such as: child's age, the accompanying person, reasons for visit, preference of doctor, children's behaviour, the experience rating and treatment suggested / rendered, and likelihood of attending the future dental visits.

The questionnaire for the parents / guardians as well as general dentists / paediatric dentists were mailed. They were asked to choose their preferred option for each question.

\section{Statistical Analysis}

The responses were received, entered on Microsoft Excel (Microsoft, Redmond, WA, USA) and analyzed using IBM SPSS version 20. Descriptive statistics was performed and the variables in the questionnaire were tested using $\chi 2$ - test to determine their association.

\section{RESULTS}

Response rates from parents, general dentists and paediatric dentists were $93.20 \%, 92.66 \%$ and $94.64 \%$ respectively. Table 1 shows the demographic data of the parents who had participated in the study. Majority of the parents were of the age range 30 to 39 years and their educational status was diploma / postgraduate (66.9\%). 63.6\% of them had monthly income of more than 5000 Saudi Riyals and $66.2 \%$ of them were employed. $91.9 \%$ of them had visited a dentist before.

Relationship between the parental factors and first dental visit was analysed using Pearson's Chi square test and described in table 2 . The parental factors that had a positive correlation with the child's first dental visit were their education status, opinion regarding appropriate child's age for first dental visit, and knowledge / awareness regarding first dental visit.

Parent's preferences and their relation to child's first dental visit has been shown in table 3. Only $6.6 \%$ of parents brought their child for dental visit within 1 year. 


\begin{tabular}{|c|c|c|}
\hline Parent's Demographic Data & $\begin{array}{c}\text { Frequency } \\
\text { (n) }\end{array}$ & $\%$ \\
\hline \multicolumn{3}{|c|}{ Parent's Age At The Time Of Their Child's First Dental Visit } \\
\hline$<20$ years & 6 & 4 \\
\hline 20 to 29 years & 36 & 23.8 \\
\hline 30 to 39 years & 62 & 41.1 \\
\hline$>40$ years & 47 & 31.1 \\
\hline \multicolumn{3}{|l|}{ Marital Status of Parent } \\
\hline Married & 135 & 89.4 \\
\hline Divorced & 11 & 7.3 \\
\hline Widowed & 5 & 3.3 \\
\hline \multicolumn{3}{|l|}{ Education Status of Parent } \\
\hline Diploma / Postgraduate & 101 & 66.9 \\
\hline Primary / Middle / Secondary School & 43 & 28.5 \\
\hline Uneducated & 7 & 4.6 \\
\hline \multicolumn{3}{|l|}{ Parent's monthly Income in Saudi Riyals } \\
\hline Less than 2000 & 33 & 21.9 \\
\hline 2000 to 4000 & 22 & 14.6 \\
\hline 5000 to 9000 & 34 & 22.5 \\
\hline More than 10,000 & 62 & 41.1 \\
\hline \multicolumn{3}{|l|}{ Frequency of Visit to Dentist } \\
\hline Sometimes or when there's an emergency. & 97 & 64.2 \\
\hline Routinely for examination or when a dental problem arises & 39 & 25.8 \\
\hline Never, I generally avoid visiting a dentist. & 15 & 9.9 \\
\hline \multicolumn{3}{|l|}{ Parents Profession } \\
\hline Professional (Doctor, Engineer...) & 30 & 19.9 \\
\hline Administrative work & 67 & 44.4 \\
\hline Craft work (Carpenter, Tailor...) & 3 & 2 \\
\hline Unemployed & 51 & 33.8 \\
\hline
\end{tabular}

\begin{tabular}{|c|c|c|}
\hline \multirow[b]{2}{*}{ Variables } & \multicolumn{2}{|c|}{$\begin{array}{c}\text { Correlation with First Child's } \\
\text { Dental Visit }\end{array}$} \\
\hline & $\begin{array}{c}\text { Pearson's } \\
\text { Chi Square } \\
\text { Value }\end{array}$ & $\begin{array}{c}P \\
\text { Value }\end{array}$ \\
\hline Parent's age & 12.326 & 0.055 \\
\hline Marital Status & 7.632 & 0.118 \\
\hline Education Status of parent & 10.147 & 0.038 \\
\hline Parent's Profession & 7.440 & 0.282 \\
\hline Monthly Income & 10.608 & 0.101 \\
\hline $\begin{array}{l}\text { Parent's opinion regarding Appropriate child's } \\
\text { age for first Dental Visit }\end{array}$ & 94.021 & 0.001 \\
\hline $\begin{array}{c}\text { Knowledge / awareness regarding first Dental } \\
\text { visit }\end{array}$ & 9.775 & 0.044 \\
\hline \multicolumn{3}{|c|}{$\begin{array}{c}\text { Table 2. Relationship between the Parental Factors } \\
\text { and First Dental Visit }\end{array}$} \\
\hline
\end{tabular}

Most parents preferred to take their child for first dental visit between 3 to 6 years. The common reasons that force them to take their child to dentist are either pain (31.8\%) or prevention of caries (31.8\%) followed by decayed teeth $(17.9$ $\%)$. Most parents preferred paediatric dentists (45\%) over general dentists (29.1\%) for their child's first dental visit. The reason for the choice was either based on their previous personal experience with the dentist (33.1\%) or belief that the treatment would be better $(28.5 \%)$ or influence by friends / peers $(21.2 \%) .98 \%$ of parents were happy with their child's first dental visit and $84.8 \%$ of them were of the opinion that they would surely go for follow - up visits. This was because they believed that dental treatment was either important (38.4 $\%$ ) or needed to be completed (35.8\%). $27.8 \%$ of parents believed that there were no barriers for the first dental visit of their child. However, when their child was not complaining of any problem $(17.9 \%)$ or their belief that primary teeth are not as important as permanent ones (13.2\%) or that child would not cooperate during dental treatment $(11.9 \%)$ were barriers for dental visit. Most of parents (41.7\%) believed that they had adequate knowledge of the first dental visit for their child.

The demographic details of the dentists who participated in the study is given in table 4 described under the variables such as work profile, gender, sector of work, and years of experience. Table 5 shows that there were statistically significant differences between practices followed by paediatric dentists and general dentists such as recommendation of time of visit, the child's age at and the treatment provided during first dental visit of the child. $86.8 \%$ of paediatric dentists had recommended first dental visit within 6 years of age when compared to $52.4 \%$ of general dentists $[p=0.001]$. None of the dentists had recommended first dental visit of children within 1 year. With regard to the treatment provided during the visit, most of general dentists $(70.3 \%)$ made sure that the chief complaint of the child is treated, when compared to paediatric dentists (56.6\%) [p = 0.048]. There were no statistically significant differences in behaviour of the child encountered by paediatric dentist and general dentist during the first dental visit $[p=0.079]$. When any invasive dental treatment was performed during first visit, the behaviour of the child in future dental visit did not vary significantly [ $p=0.079]$. However, there was a minor increase in negative behaviour observed.

\begin{tabular}{|c|c|c|}
\hline Variables & Frequency (n) & $\%$ \\
\hline \multicolumn{3}{|l|}{ Child's age During First Dentist Visit } \\
\hline Less than 1 year & 10 & 6.6 \\
\hline 1 to less than 3 years & 42 & 27.8 \\
\hline 3 to $<6$ years & 55 & 36.4 \\
\hline 6 to $<9$ years & 26 & 17.2 \\
\hline 9 years and above & 18 & 11.9 \\
\hline \multicolumn{3}{|l|}{ Reason for First Dental Visit } \\
\hline As advised by schoolteacher / relatives / friends & 12 & 7.9 \\
\hline As recommended by child's paediatricians during check- ups & 4 & 2.6 \\
\hline Prevention of caries & 48 & 31.8 \\
\hline Pain & 48 & 31.8 \\
\hline Decayed teeth or its filling & 27 & 17.9 \\
\hline Late eruption of permanent due to over - retained milk tooth & 4 & 2.6 \\
\hline Treatment of crowded teeth & 3 & 2 \\
\hline Trauma to teeth, soft tissues of oral cavity or jaws & 5 & 3.3 \\
\hline \multicolumn{3}{|c|}{ Preference of Doctor for Consultation for Child's First Dental Visit? } \\
\hline General Dentist & 44 & 29.1 \\
\hline Paediatric Dentist & 68 & 45 \\
\hline Family physician & 8 & 5.3 \\
\hline Others & 31 & 20.5 \\
\hline \multicolumn{3}{|c|}{ Reason for Choosing the preference of Doctor - GD or PD } \\
\hline Based on my previous experience with the dentist & 50 & 33.1 \\
\hline I believe the quality of the treatment is better. & 43 & 28.5 \\
\hline His clinic is near my house. & 20 & 13.2 \\
\hline My friends / relatives advised me & 32 & 21.2 \\
\hline Other reasons & 6 & 4 \\
\hline \multicolumn{3}{|c|}{ Parents' Overall Experience First Dental Visit } \\
\hline Good & 107 & 70.9 \\
\hline Satisfactory & 41 & 27.2 \\
\hline Bad & 3 & 2 \\
\hline \multicolumn{3}{|c|}{$\begin{array}{l}\text { Based on Experience of First Dental Visit, the Likelihood of Attending Next } \\
\text { Appointment? }\end{array}$} \\
\hline Yes & 128 & 84.8 \\
\hline May be & 19 & 12.6 \\
\hline No & 4 & 2.6 \\
\hline \multicolumn{3}{|c|}{ If Answer to Previous Question was Yes, Why? } \\
\hline Behaviour of dental professionals & 19 & 12.6 \\
\hline For completing my treatment & 54 & 35.8 \\
\hline Importance of dental treatment & 58 & 38.4 \\
\hline The treatment provided relieved my problem & 14 & 9.3 \\
\hline Others & 6 & 4 \\
\hline \multicolumn{3}{|c|}{ Parents Perception Regarding Barrier for Child's First Dental Visit } \\
\hline No, I can take my child to the dentist & 42 & 27.8 \\
\hline Yes, because I am very busy & 5 & 3.3 \\
\hline $\begin{array}{l}\text { I believe primary teeth are not as important as permanent } \\
\text { teeth. }\end{array}$ & 20 & 13.2 \\
\hline There is no real need to go to the dentist at a young age & 11 & 7.3 \\
\hline Lack of transportation & 3 & 2 \\
\hline Lack of appointments & 13 & 8.6 \\
\hline My child will be uncooperative with the dentist & 18 & 11.9 \\
\hline My child is not complaining from dental problem & 27 & 17.9 \\
\hline I am afraid of dentists & 12 & 7.9 \\
\hline \multicolumn{3}{|c|}{ Parent's Self - Perception Regarding Knowledge of First Dental Visit for their Child } \\
\hline Yes, I do have required knowledge & 63 & 41.7 \\
\hline I don't know whether I have the knowledge & 52 & 34.4 \\
\hline I do not have the knowledge & 36 & 23.8 \\
\hline
\end{tabular}




\begin{tabular}{|c|c|c|}
\hline Variable & Frequency (n) & $\%$ \\
\hline \multicolumn{3}{|c|}{ Work Profile of Dentists } \\
\hline General Dentists & 101 & 65.6 \\
\hline Paediatric Dentists & 53 & 34.4 \\
\hline \multicolumn{3}{|c|}{ Gender of the Dentists } \\
\hline Male & 83 & 53.9 \\
\hline Female & 71 & 46.1 \\
\hline \multicolumn{3}{|c|}{ Sector of Work } \\
\hline Government & 81 & 52.6 \\
\hline Private & 73 & 47.4 \\
\hline \multicolumn{3}{|c|}{ Type of Work } \\
\hline Academician & 51 & 33.1 \\
\hline Clinician & 103 & 66.9 \\
\hline \multicolumn{3}{|c|}{ Number of Years of Experience } \\
\hline Less than 5 years & 80 & 51.9 \\
\hline 5 to $<10$ years & 38 & 24.7 \\
\hline 10 to $<20$ years & 28 & 18.2 \\
\hline$\geq 20$ years & 8 & 5.2 \\
\hline
\end{tabular}

\begin{tabular}{|c|c|c|c|c|}
\hline \multirow[b]{2}{*}{ Variables } & \multicolumn{2}{|c|}{ Groups } & \multirow[b]{2}{*}{$\begin{array}{l}\text { Chi } \\
\text { Square } \\
\text { Value }\end{array}$} & \multirow[b]{2}{*}{$\begin{array}{c}\text { p - } \\
\text { Value }\end{array}$} \\
\hline & $\begin{array}{l}\text { General } \\
\text { Dentist } \\
\text { N (\%) }\end{array}$ & $\begin{array}{l}\text { Paediatric } \\
\text { Dentist } \\
\text { N (\%) }\end{array}$ & & \\
\hline \multicolumn{5}{|c|}{ Dentists Recommendation of First Dental Visit of the Child } \\
\hline Less than 1 year & $0(0)$ & $0(0)$ & \multirow{5}{*}{20.251} & \multirow{5}{*}{0.001} \\
\hline 1 to $<3$ years & $06(5.9 \%)$ & $09(17 \%)$ & & \\
\hline 3 to $<6$ years & $47(46.5 \%)$ & 37 (69.8 \%) & & \\
\hline 6 to $<9$ years & $37(36.6 \%)$ & $07(13.2 \%)$ & & \\
\hline 9 years and above & $11(10.9 \%)$ & $0(0)$ & & \\
\hline \multicolumn{5}{|c|}{ Treatment Provided During Child's First Dental Visit } \\
\hline Chief complaint of the child is treated & $71(70.3 \%)$ & $30(56.6 \%)$ & \multirow{4}{*}{7.915} & \multirow{4}{*}{0.048} \\
\hline $\begin{array}{l}\text { Only Dental examination / } \mathrm{x} \text { - ray is } \\
\text { done }\end{array}$ & 12 (11.9\%) & $15(28.3 \%)$ & & \\
\hline Only medication is prescribed & $3(3 \%)$ & $0(0)$ & & \\
\hline Only advice is given & $15(14.9 \%)$ & $8(15.1 \%)$ & & \\
\hline \multicolumn{5}{|c|}{ Behaviour of the Child Observed During First Dental Visit } \\
\hline Definitely positive & $5(5 \%)$ & $0(0)$ & \multirow{4}{*}{6.789} & \multirow{4}{*}{0.079} \\
\hline Positive & $38(37$ & $28(52.8 \%)$ & & \\
\hline Negative & $52(5$ & $25(47$. & & \\
\hline Definitely negative & $6(5.9 \%)$ & $0(0)$ & & \\
\hline \multicolumn{5}{|c|}{$\begin{array}{l}\text { If any Invasive Dental Treatment is Performed, the Behaviour of the Child in Future } \\
\text { Dental Visit }\end{array}$} \\
\hline Definitely positive & $5(5 \%)$ & $0(0 \%)$ & \multirow{4}{*}{6.789} & \multirow{4}{*}{0.079} \\
\hline Positive & $30(29.7 \%)$ & $9(17.0 \%)$ & & \\
\hline Negative & $54(53.5 \%)$ & 38 (71.7 \%) & & \\
\hline Definitely negative & $12(11.9 \%)$ & $6(11.3 \%)$ & & \\
\hline \multirow{2}{*}{\multicolumn{5}{|c|}{$\begin{array}{c}\text { Behaviour Management Technique Performed during First Dental Visit that is } \\
\text { Believed to be most Promising in that Instills Positive Child Behaviour at Future } \\
\text { Visits }\end{array}$}} \\
\hline & & & & \\
\hline Tell show do & $36(35.6 \%)$ & $31(58.5 \%)$ & \multirow{4}{*}{10.11} & \multirow{4}{*}{0.018} \\
\hline Positive reinforcement & $34(33.7 \%)$ & $16(30.2 \%)$ & & \\
\hline Communication & $28(27.7 \%)$ & $6(11.3 \%)$ & & \\
\hline Voice control & $3(3.0 \%)$ & $0(0 \%)$ & & \\
\hline \multicolumn{5}{|c|}{ Knowledge regarding successfully managing child during first dental visit } \\
\hline $\begin{array}{l}\text { I am having required knowledge and } \\
\text { expertise }\end{array}$ & $31(30.7 \%)$ & $28(52.80 \%)$ & \multirow{3}{*}{8.801} & \multirow{3}{*}{0.01} \\
\hline $\begin{array}{l}\text { I believe that regular updating with } \\
\text { continuing dental education is } \\
\text { required }\end{array}$ & $64(63.4 \%)$ & $25(47.2 \%)$ & & \\
\hline $\begin{array}{l}\text { I am not having the knowledge and } \\
\text { expertise. }\end{array}$ & $6(5.9 \%)$ & $0(0 \%)$ & & \\
\hline \multicolumn{5}{|c|}{ Table 5. Dentists' Practices Regarding First Dental Visit of the Child } \\
\hline
\end{tabular}

Tell show do technique of behaviour shaping was believed to be most promising in instilling a positive dental attitude by $58.5 \%$ of paediatric dentists and $35.6 \%$ of general dentists [p $=0.018]$. Positive reinforcement was the second commonly preferred technique. Voice control technique was seldom used by paediatric dentists. Most paediatric dentists [52.8 \%] were of the opinion that they had enough knowledge and expertise for successfully managing a child during first dental visit whereas most general dentists [63.4\%] believed that they need to update themselves by continuing dental education [p $=0.01$.

Table 6 describes the clinical examination or tasks performed by dentists during first dental visit. The paediatric dentists were more frequently recording general health / growth $[p=0.001]$, performing extra - oral \& intra - oral examinations $[p=0.001]$ and evaluating developing dentition $[p=0.001]$ when compared to general dentists. Whereas both groups had similar preferences regarding evaluating caries risk and performing invasive dental treatment.

\begin{tabular}{|c|c|c|c|c|c|c|c|}
\hline \multirow{2}{*}{ 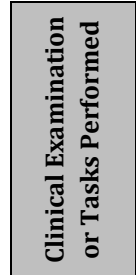 } & \multirow[b]{2}{*}{ 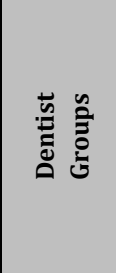 } & \multicolumn{4}{|c|}{$\begin{array}{c}\text { Frequency of Performing the } \\
\text { Task }\end{array}$} & \multirow{2}{*}{ 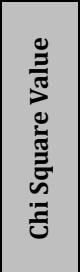 } & \multirow[b]{2}{*}{$\begin{array}{l}\frac{0}{3} \\
\frac{\pi}{1} \\
2\end{array}$} \\
\hline & & 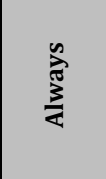 & 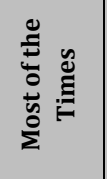 & 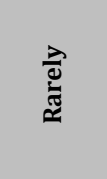 & $\frac{\grave{d}}{z}$ & & \\
\hline \multirow{2}{*}{$\begin{array}{c}\text { Record } \\
\text { General } \\
\text { Health / } \\
\text { Growth }\end{array}$} & $\begin{array}{c}\text { General } \\
\text { Dentist } \\
\mathrm{N}(\%)\end{array}$ & $\begin{array}{c}21 \\
(20.8 \%)\end{array}$ & $\begin{array}{c}58 \\
(57.4 \%)\end{array}$ & $\begin{array}{c}18 \\
(17.8 \%)\end{array}$ & $\begin{array}{c}04 \\
(4 \%)\end{array}$ & \multirow[b]{2}{*}{26.677} & \multirow[b]{2}{*}{0.001} \\
\hline & $\begin{array}{c}\text { Pediatric } \\
\text { Dentist } \\
\mathrm{N}(\%) \\
\end{array}$ & $\begin{array}{c}19 \\
(35.8 \%)\end{array}$ & $\begin{array}{c}77 \\
(50 \%)\end{array}$ & $\begin{array}{c}01 \\
(1.9 \%)\end{array}$ & $\begin{array}{c}01 \\
(1.9 \%)\end{array}$ & & \\
\hline \multirow{2}{*}{$\begin{array}{c}\text { Perform } \\
\text { Extra oral } \\
\text { Examination }\end{array}$} & $\begin{array}{l}\text { General } \\
\text { Dentist } \\
\mathrm{N}(\%)\end{array}$ & $\begin{array}{c}17 \\
(16.8 \%)\end{array}$ & $\begin{array}{c}25 \\
(24.8 \%)\end{array}$ & $\begin{array}{c}36 \\
(35.6 \%)\end{array}$ & $\begin{array}{c}23 \\
(22.8 \%)\end{array}$ & \multirow[b]{2}{*}{25.859} & \multirow[b]{2}{*}{0.001} \\
\hline & $\begin{array}{c}\text { Pediatric } \\
\text { Dentist } \\
\mathrm{N}(\%)\end{array}$ & $\begin{array}{c}21 \\
(39.6 \%)\end{array}$ & $\begin{array}{c}22 \\
(41.5 \%)\end{array}$ & $\begin{array}{c}10 \\
(18.5 \%)\end{array}$ & $\begin{array}{c}0 \\
(0)\end{array}$ & & \\
\hline \multirow{2}{*}{$\begin{array}{c}\text { Perform } \\
\text { Intra - Oral } \\
\text { soft \& hard } \\
\text { Tissues }\end{array}$} & $\begin{array}{l}\text { General } \\
\text { Dentist } \\
\mathrm{N}(\%) \\
\end{array}$ & $\begin{array}{c}47 \\
(46.5 \%)\end{array}$ & $\begin{array}{c}37 \\
(36.6 \%)\end{array}$ & $\begin{array}{c}11 \\
(10.9 \%)\end{array}$ & $\left|\begin{array}{c}06 \\
(5.9 \%)\end{array}\right|$ & \multirow[b]{2}{*}{23.006} & \multirow[b]{2}{*}{0.001} \\
\hline & $\begin{array}{c}\text { Pediatric } \\
\text { Dentist } \\
\mathrm{N}(\%)\end{array}$ & $\begin{array}{c}45 \\
(84.9 \%)\end{array}$ & $\begin{array}{c}08 \\
(15.1 \%)\end{array}$ & $\begin{array}{c}0 \\
(0)\end{array}$ & $\begin{array}{c}0 \\
(0)\end{array}$ & & \\
\hline \multirow{2}{*}{\begin{tabular}{|c|} 
Perform \\
Invasive \\
Dental \\
Treatment
\end{tabular}} & $\begin{array}{c}\text { General } \\
\text { Dentist } \\
\mathrm{N}(\%)\end{array}$ & $\begin{array}{c}0 \\
(0)\end{array}$ & $\begin{array}{c}02 \\
(2 \%)\end{array}$ & $\begin{array}{c}73 \\
(72.3 \%)\end{array}$ & $\left|\begin{array}{c}26 \\
(25.7 \%)\end{array}\right|$ & \multirow[b]{2}{*}{4.429} & \multirow[b]{2}{*}{0.109} \\
\hline & $\begin{array}{c}\text { Pediatric } \\
\text { Dentist } \\
\mathrm{N}(\%)\end{array}$ & $\begin{array}{c}0 \\
(0)\end{array}$ & \begin{tabular}{c|c}
01 \\
$(1.9 \%)$
\end{tabular} & $\begin{array}{c}46 \\
(86.8 \%)\end{array}$ & $\begin{array}{c}06 \\
(11.3 \%)\end{array}$ & & \\
\hline \multirow{2}{*}{\begin{tabular}{|c|} 
Evaluate \\
Developing \\
Occlusion
\end{tabular}} & $\begin{array}{l}\text { General } \\
\text { Dentist } \\
\mathrm{N}(\%)\end{array}$ & $\begin{array}{c}33 \\
(32.7 \%)\end{array}$ & $\begin{array}{c}35 \\
(34.7 \%)\end{array}$ & $\begin{array}{c}25 \\
(24.8 \%)\end{array}$ & $\begin{array}{c}08 \\
(7.9 \%)\end{array}$ & \multirow[b]{2}{*}{28.073} & \multirow[b]{2}{*}{0.001} \\
\hline & $\begin{array}{c}\text { Pediatric } \\
\text { Dentist } \\
\mathrm{N}(\%) \\
\end{array}$ & $\begin{array}{c}37 \\
(69.8 \%)\end{array}$ & $\begin{array}{c}16 \\
(30.2 \%)\end{array}$ & $\begin{array}{c}0 \\
(0)\end{array}$ & $\begin{array}{c}0 \\
(0)\end{array}$ & & \\
\hline \multirow{2}{*}{$\begin{array}{c}\text { Evaluate } \\
\text { Caries } \\
\text { Risk }\end{array}$} & $\begin{array}{l}\text { General } \\
\text { Dentist } \\
\mathrm{N}(\%) \\
\end{array}$ & $\begin{array}{c}54 \\
(53.5 \%)\end{array}$ & $\begin{array}{c}35 \\
(34.7 \%)\end{array}$ & $\begin{array}{c}09 \\
(8.9 \%)\end{array}$ & \begin{tabular}{c|c}
0 \\
$3(3 \%)$
\end{tabular} & \multirow[b]{2}{*}{5.936} & \multirow[b]{2}{*}{0.115} \\
\hline & \begin{tabular}{|l} 
Pediatric \\
Dentist \\
$\mathrm{N}(\%)$
\end{tabular} & $\begin{array}{c}38 \\
(71.7 \%)\end{array}$ & $\begin{array}{c}13 \\
(24.5 \%)\end{array}$ & $\begin{array}{c}02 \\
(3.8 \%)\end{array}$ & $0(0)$ & & \\
\hline \multicolumn{8}{|c|}{$\begin{array}{l}\text { Table 6. Clinical Examination or Tasks Performed by } \\
\text { Dentists during the First Dental Visit }\end{array}$} \\
\hline
\end{tabular}

\section{DISCUSSION}

It is appropriate to consider the first dental visit of a child as an important milestone after understanding the fact that a child can succumb to dental caries as early as less than 12 months. ${ }^{7}$ By the time a child reaches kindergarten, it has been reported that $28 \%$ of them could have caries. ${ }^{8} 89 \%$ of children aged one year have been reported to visit their physician when compared to only $1.5 \%$ who visited dental. ${ }^{9}$ Hence, these findings make such studies necessary to understand the perspectives of parents' as well as general / paediatric dentists' point of view to battle the dental diseases at grass root level.

It has been recommended that the first dental visit should be scheduled as early as 6 months from the time first primary tooth has erupted but no later than one year. ${ }^{10}$ This early visit helps in gaining the advantages of early preventive care 
thereby promoting better cost - effective oral health maintenance. ${ }^{11}$

Yet reports across many developing countries such as India suggest that first dental visit is common between 7 and 9 years. ${ }^{12}$ On the contrary, countries such as Saudi Arabia ${ }^{13}$ and USA ${ }^{14}$ suggests an early timing of $3-5$ years and $2-4$ years respectively which is in accordance to the present study. Most children prior to preschool in Australia rarely get to see the dentist before the age of 5.15 Only $2 \%$ of children living in USA belonging to less than 3 years of age group have the privilege of dental visit during their first year of life. 16

The present study has shown that pain and / or prevention of caries were the reasons for the first dental visit; which is in accordance to data obtained from similar studies.12,13,17 $\mathrm{A}$ contrary Bulgarian study suggests that dental caries (59.8\%) followed by pain $(16.2 \%)$ were the reasons for the dental visit. 18 The perception among the masses that primary teeth will eventually shed off and hence do not need treatment unless there is pain may be the reason for delaying treatment. 13

It is reported that parents would take their children to a physician / paediatrician rather than their dentist during the preschool age for preventive dental care. ${ }^{19,20}$ The majority of paediatricians and general dentists are not referring their patients to the paediatric dentists by 1 year of age which implies that it is the need of the hour to educate them regarding infant oral health care. ${ }^{21}$ In the present study, parents chose to consult either a paediatric dentist or a general dentist for their child's first dental visit rather than other health care personnel. However, their awareness needs to be improved regarding the importance of the first dental visit at age one, especially among physicians / paediatricians and also other non - dental professionals.

It has been reported that the reason for not availing early dental care was that the child did not have any dental problem which could be attributed to the decreased awareness among parents regarding dental caries disease dynamics and its prevention. Parents of these very young children were of the opinion that their child would not cooperate. This was coupled by the fact that the $42 \%$ parents were not aware of the specialty of paediatric dentistry that was available for dental care of their children. ${ }^{22}$ In the present study, parents past dental experience was found to be determining where they would prefer their child to undergo their first dental visit. It has been reported that whatever may be the educational status of parents, most of them were unaware regarding the timing of first dental visit. ${ }^{23}$

Children have been reported to exhibit positive behaviour $(39.67 \%)$ during their first dental visit, similar to the results of the present study. This could be due to the conducive environment during treatment or the age group involved, as 3 - 6 years age group children tend to be more cooperative than their younger counterparts. The probability of increasing the negative behaviour was found to be high, if invasive treatment was performed during first visit, as observed in the present study. ${ }^{13}$

Behaviour shaping techniques such as tell - show - do, reinforcement, distraction, and parental involvement have been used by dentists for achieving better cooperation during present and future dental visits. However, more aggressive techniques like voice control and hand over mouth exercise would be sometimes required to reduce the potential inappropriate child behaviour, although they are less accepted by parents / children. ${ }^{24}$

The experience during first dental visit enables the parent to decide the likelihood of attending next appointment, as shown in the present study. A study revealed that majority of children were happy regarding the dental treatment for which they came to dentist, and hence their parents were reported to be satisfied with overall experience of their child's first dental visit. Around $84.8 \%$ of the parents in the present study had suggested they would report to next appointment which suggests that they were satisfied with the dental treatment of their child during the first visit. This was because they believed that dental treatment was either important (38.4\%) or had to be completed (35.8\%).

It is also imperative that all dentists must recommend to parents regarding the establishment of dental home by one year of age, ${ }^{10}$ and perform a thorough examination along with a good history taking. It is at this age that a paediatric dentist should try to foresee the caries risk in an infant and plan an appropriate age specific treatment plan. This would require good parent compliance and motivation as it necessitates multiple dental visits.

However, many dentists suggest to parents that as the child's ability to cooperate is less owing to the younger age, it would be an advantage to postpone the treatment till the child is old enough. Such suggestions could influence the decision making regarding postponing the treatment. ${ }^{25}$ Parents in UK preferred that dentists should make these decisions reflecting the existing confusion between parents and dentists. Parents have limited understanding of disease conditions and cannot decide on treatment options that would be better. ${ }^{26}$ Hence, the dentist should be educating such parents regarding the pros of early dental visit for their children so that they willingly give consent for treatment.

\section{CONCLUSIONS}

Only $6.6 \%$ of parents take their children for first dental visit within first year of their child's life. Most of the paediatric dentists and general dentists recommend the first dental visit in children between 3 to 6 years. However, none of them recommended the dental visit before 12 months of age.

Findings of this study should alert the dental professionals, paediatricians, gynecologists and other health workers to work as a team to increase awareness among the public regarding importance of early dental visits before 12 months of age. During the dental visit, the dentist should proactively counsel parents / care givers of the child and educate them regarding oral hygiene maintenance, correct feeding practices, trauma to teeth, benefits / appropriate use of fluoride and diet counseling. Socioeconomic and clinical indicators play an important role in determining the use of dental services, which necessitates the need for instituting dental education focused at community as well as school levels to facilitate better reach in increasing the awareness.

Data sharing statement provided by the authors is available with the full text of this article at jemds.com.

Financial or other competing interests: None.

Disclosure forms provided by the authors are available with the full text of this article at jemds.com. 


\section{REFERENCES}

[1] Nino J, Ashino J, Varsha J, et al. First dental visit of a child: a retrospective study. Pushpagiri Med J 2010;2(1):21-3.

[2] Friedman LA, Mackler IG, Hoggard GJ, et al. A comparison of perceived and actual dental needs of a select group of children in Texas. Community Dent Oral Epidemiol 1976;4(3):89-93.

[3] Al-Shalan TA, Al-Mousa BA, Al-Khamis AM. Parents' attitude toward children's first dental visit in college of dentistry, Riyadh, Saudi Arabia. Saudi Med J 2002;23(9):1110-4.

[4] Eijkman MA, Houwink B, de With C. Some aspects of patient education by dentist of mothers with young children. Neth Dent J 1978;85(7-8):304-15.

[5] Klinberg G. Dental anxiety and behaviour management problems in paediatric dentistry - a review of background factors and diagnostics. Eur Arch Paediatr Dent 2008;9(Suppl 1):11-5.

[6] Alshahrani NF, Alshahrani ANA, Alahmari MA, et al. First dental visit: age, reason and experiences of Saudi children. Eur J Dent 2018;12(4):579-84.

[7] Baliga MS. Child's first dental visit in India: a reappraisal. J Indian Soc Pedod Prev Dent 2019;37(2):113-4.

[8] National Institute of Dental and Craniofacial Research. Dental caries (tooth decay) in children Age 2 to 11. May 2014. http: / / www.nidcr.nih.gov / Data Statistics / FindDataByTopic / DentalCaries / DentalCariesChildren2to11.htm

[9] National Children's Oral Health Foundation. Facts about tooth decay. http: / / www.ncohf.org / resources / tooth decay - facts.

[10] American academy of paediatric dentistry: guideline on infant oral health care. paediatr Dent 2014;36:1141-5.

[11] Hale KJ. Oral health risk assessment timing and establishment of the dental home. paediatrics 2003;111(5 Pt 1):1113-6.

[12] Dave B, Patel R, Bargale S, et al. $1^{\text {st }}$ dental visit: an ounce of prevention is worth a pound of cure. RRJDS 2019;7(1):8-13.

[13] Murshid EZ. Children's ages and reasons for receiving their first dental visit in a Saudi community. Saudi Dent J 2016;28(3):142-7.
[14] Nainar SMH, Straffon LH. Targeting of the year one dental visit for United States children. Int J Paediatr Dent 2003;13(4):258-63.

[15] Widmer R. The first dental visit: an Australian perspective. Int J Paediatr Dent 2003;13(4):270.

[16] Slayton RL, Warren JJ, Levy SM, et al. Frequency of reported dental visits and professional fluoride applications in a cohort of children followed from birth to age 3 years. paediatr Dent 2002;24(1):64-8.

[17] Meera R, Muthu MS, Phanibabu M, et al. First dental visit of a child. J Indian Soc Pedod Prev Dent 2008;26(Suppl 2):68-71.

[18] Mileva SP, Kondeva VK. Age at and reasons for the first dental visit. Folia Med (Plovdiv) 2010;52(4):56-61.

[19] Kranz AM, Preisser JS, Rozier RG. Effects of physicianbased preventive oral health services on dental caries. paediatrics 2015;136(1):107-14.

[20] Olatosi OO, Sote EO, Akinsola OJ, et al. Prevention of dental caries: knowledge, practice and opinion of paediatricians in Lagos. West Afr J Med 2013;32(1):52-6.

[21] Brickhouse TH, Unkel JH, Kancitis I, et al. Infant oral health care: a survey of general dentists, paediatric dentists and paediatricians in Virginia. paediatr Dent 2008;30(2):14753.

[22] Bhagat D, Khan MHA, Uddin MA. Barriers for parental failure in bringing their children to the dental Clinic- a questionnaire - based study in Indian population. Indian J Mednodent Allied Sci 2014;2(1):17-20.

[23] Sanguida A, Vinothini V, Prathima GS, et al. Age and reasons for first dental visit and knowledge and attitude of parents toward dental procedures for Puducherry children aged 0-9 years. J Pharm Bioallied Sci 2019;11(Suppl 2):S413-9.

[24] Efron LA, Sherman JA. Five tips for managing paediatric dental anxiety. Dent Today 2005;24(6):104-5.

[25] Wong D, Perez-Spiess S, Julliard K. Attitudes of Chinese parents toward the oral health of their children with caries: a qualitative study. paediatr Dent 2005;27(6):50512.

[26] Alshehri A, Nasim VS. Infant oral health care knowledge and awareness among parents in Abha city of Aseer Region, Saudi Arabia. Saudi J Dent Res 2015;6(2):98-101. 